\title{
濃厚コロイド系の界面動電現象
}

\section{Electrokinetics in Highly Concentrated Colloid Systems}

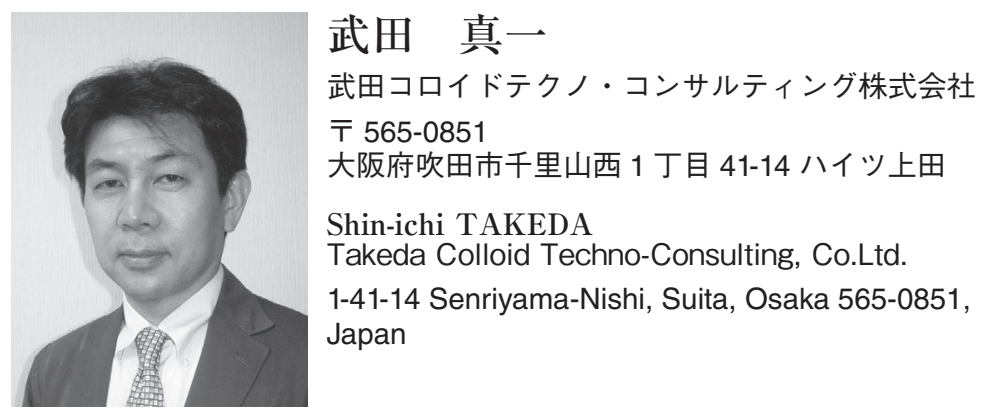

論文要旨：濃厚コロイド系での界面動電現象について, 最近とくに注目されている超音波式ゼー夕電位測 定法を中心に歴史的背景ならびに理論的背景, 測定例を紹介した。理論的背景は沈降電位で観察される電気 二重層の変形問題に深く関係しているので，この点を説明したのち，その類似の考え方としてコロイド振動 電流法 (CVI 法) と電気音響法（ESA 法）の概念を説明した。濃厚系では，粒子間相互作用の有無により 理論式が大きく異なるので粒子間相互作用の有る系とない系での理論式を簡単に紹介した。

Abstract: Electrokinetics in highly concentrated colloid systems were reviewed and introduction of the background of historical and theoretical aspects on electroacoustics was emphasized, because electroacoustics has attracted much interests from academic and industrial fields recently. The theoretical aspects on CVI and ESA, being developed based upon the concept of sedimentation potential in terms of EDL deformation, were explained. In the highly concentrated systems, since particle - particle interactions play an important role for describing the relationship between zeta potential and dynamic electrophoretic mobility, two typical cases with/without interactions were shown.

Key words: concentrated colloid systems, CVI, zeta potential, dynamic electrophoretic mobility

\section{1 はじめに}

溶媒中に分散したコロイド粒子は一般に界面に電荷を 有する。系全体としては電気的中性が保たれるので, 粒 子界面の周辺には粒子の電荷と反対符号のいわゆる対イ オンと呼ばれるイオンがとり囲み界面電気二重層を形成 する。界面電気二重層のために, 電気泳動, 電気浸透, 流動電位，沈降電位などの界面電気現象を示すが，これ らの挙動を支配するのは粒子と媒質の相対運動が生じる すべり面の電位, すなわちゼー夕電位である。電気二重 層をもつ二つのコロイド粒子が接近すると, ファン・デ ル・ワールスカと電気二重層間の相互作用による静電的 な斥力が働き,この 2 種の力の釣り合いによって粒子間 に働く力がきまる。粒子濃度が低い場合には，ブラウン 運動する粒子が互いに近づいた時の相互作用を考慮すれ ば良いが，粒子濃度が高くなってくるとその分，粒子間

連絡者：武田 真一

E-mail :stakeda@tctc.jp
距離が短くなるので, 粒子径がナノ粒子のように小さい 場合には電気二重層の重なりが生じるなどの特異的な現 象が起こる。本稿では, 実用分散系への適用も考慮して 粒子濃度が数重量\%以上の濃厚系での界面動電現象につ いて解説する。

\section{2 濃厚コロイド系で観測される界面動電現象}

界面動電現象は広範なコロイド粒子濃度で観測される が，一般に普及しているゼー夕電位測定装置の中では, 電気泳動法など粒子濃度希薄系に適用できる手法のもの が現在では主流である。そのため, 本質的には測定対象 もモデル化した系など希薄系が適しているので，これま で多くの研究が希薄系を中心に行われ, 理論も希薄系に 対するものが多く提案されてきた。一方，塗料やインク など実用濃厚系の分散安定性に関する研究は 1960 年代 にすでに開始され ${ }^{1)}$, 流動電位現象やその逆の現象であ る沈降電位の測定が試みられてきた。さらに 1980 年代 に入るとファイン・セラミックスなどの湿式製造プロセ 
スに関する研究が活発化し，粒子濃度が 30〜 40 体積\% を超えるようなスラリー中の分散安定性を評価したいと いう需要が高まり, 工学的な観点から再び濃厚系ゼー夕 電位測定に興味が持たれ始めた。その結果として，米国 で開発された超音波方式濃厚系用ゼー夕電位 (Colloid Vibration Potential : CVP) 測定装置（Pen Kem7000, 米国 Pen Kem Inc.) が 1980 年代中頃から日本でも上市 されるようになった。装置が開発された 80 年代は, コ ロイド振動電位 CVP（Colloid Vibration Potential）を検 出していたが, 92 年以降は検出感度, 再現性の点でより 優れているコロイド振動電流 CVI (Colloid Vibration Current）を検出する形式に改良されている。本稿では, 当時使用されていた呼び名を用いている関係で CVP と CVI の両方の表記があるが，本質的には同一の機構で測 定を行っているので，同義語として扱って頂きたい。

Fig. 1 に各ゼー夕電位評価装置の特徴と位置づけが分 かり易いように，粒子濃度と印加する周波数で測定手法 を分類してみた。電気泳動法は図からも明らかなように 適用可能な系の粒子濃度は低く，両電極間の極性を速く ても 1 2 分程度で数回程度反転できるような低周波数 域で測定される手法である。この場合，電場を印加して 粒子を移動させるので駆動力は電場であるが, この電場 の印加周波数を速くすると ESA（Electric Sonic Amplitude：ESA）法になる ${ }^{2)}$ 。この手法は，帯電粒子を交流 の高周波数域で振動させることにより発生した超音波の 音圧変動から粒子の带電状態，すなわちゼー夕電位が評 価できる。粒子を移動させるために外部から電場を印加 する点が電気泳動法との共通点である。

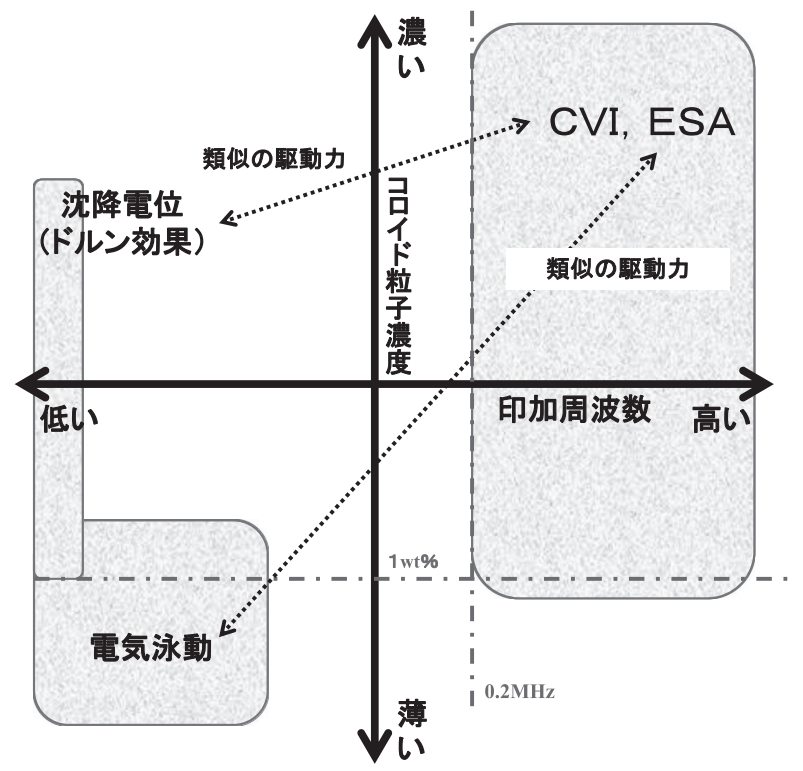

Fig. 1 界面動電現象のコロイド粒子濃度および印加周波数 による分類
次に沈降電位法について述べる。この手法は電気泳動 法と同様に古くから使用され, 粒子濃度が濃い系でも適 用可能な手法として塗料などの系に対して適用されてき た。とくに非水溶媒系でも評価可能である点が特徵で あった。この手法の場合, 粒子が小さいと沈降し難いの で短時間で沈降（溶媒に対して相対運動）させるのに遠 心力を利用していたが，この相対運動のための駆動力を 超音波に変えたものがColloid Vibration Potential(CVP) 法 $^{3)}$, 別名，超音波法である。

Fig. 1 に示したように, 現時点で濃厚コロイド系に対 して適用可能な手法は沈降電位法, CVP (CVI) 法, ESA 法であるが，本稿では紙面の都合上，高周波数測定 法の基礎になったドルン効果 (Dorn Effect) ${ }^{4)}$ を用いた沈 降電位法について簡単に紹介した後, 現在濃厚系評価法

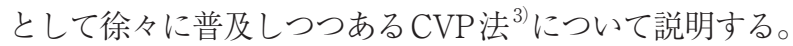

\section{3 沈降電位法とドルン効果 $(\text { Dorn Effect) })^{4)}$}

溶媒中を沈降する荷電粒子は, 電気二重層の拡散部分 を後へ置き去りにする傾向がある。荷電粒子を入れた沈 降管の底部と頂部の近くに各々電極を設置すると, 荷電 粒子が沈降する場合この二つの電極間に電位差が発生す る (Fig. 2 参照)。この場合, 沈降する方向の単位長さ 当たりに発生する電位差 $\mathrm{E}_{\mathrm{sed}}$ を沈降電位と呼ぶ。また, このような効果は 1878 年 Dornにより報告され ${ }^{4)}, \quad$ ド ルン効果 (Dorn Effect) と呼ばれている。電位差が発 生する理由は, 粒子が沈降する際, 各粒子を取り囲む電 気二重層は粒子表面を通過する流体流れの影響を受けて 対称性を失い変形する。例えば, 粒子が負に带電してい るとすると, 過剩なカチオンが拡散層から剥ぎ取られ粒 子上部に残され，双極子を形成する (Fig. 3 参照)。粒 子濃度が高い場合には，この双極子が蓄積することによ り巨視的には測定可能な電位差として検出される。スモ

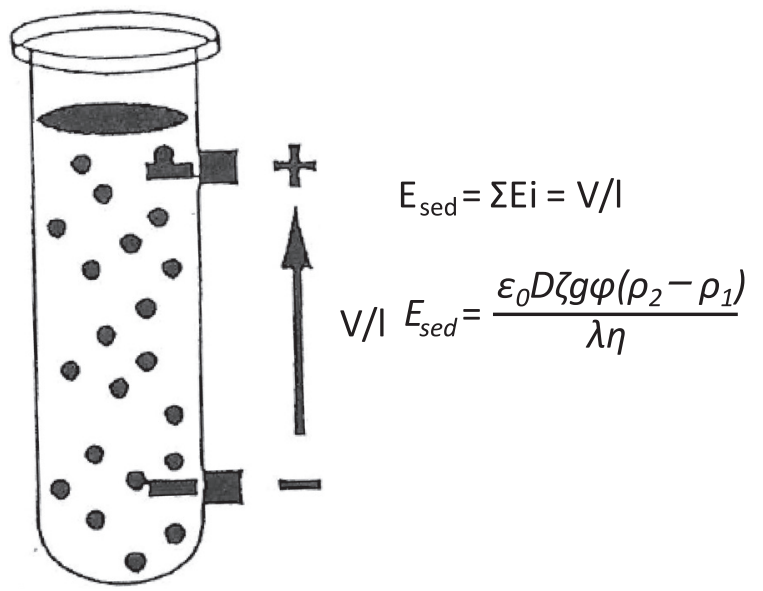

Fig. 2 沈降管の底部と頂部の電極間に発生する沈降電位 $\mathrm{E}_{\mathrm{sed}}$ 
Counter ions distributed symetrically

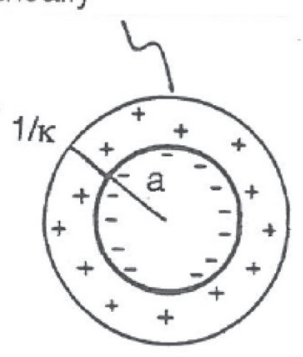

A.Static state
Counter ions lag behind particle

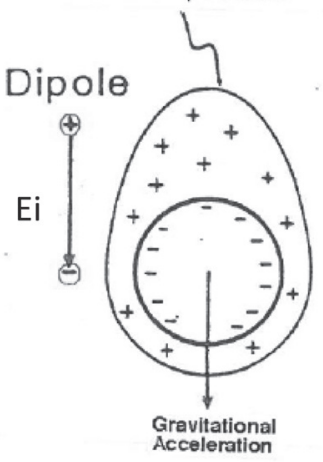

B. Gravitational acceleration
Fig. 3 Dorn Effectの模式図. a) 粒子停止状態のときの二 重層の状態，b）沈降時の二重層の状態.

ルコフスキーは 1914 年にこの電位差の大きさが理論的 に求まることを報告した ${ }^{5)}$ 。次の 5 つの仮定が成り立つ 際に式（1）が成り立ち, 電位差が求まる。

$$
E=\frac{\varepsilon_{0} D \zeta g \phi\left(\rho_{2}-\rho_{1}\right)}{\lambda \eta}
$$

その仮定とは，1）粒子は球形, 非伝導性, 単分散であ ること，2）粒子は小さく，遠心力場で層流として沈降 すること，3）粒子間相互作用は無視できること，4）表 面伝導度は無視できること（粒子の荷電による沈降速度 の遅れは無視すること），5）二重層厚さ $1 /$ には粒子半 径 $\mathrm{a}$ よ小さい $(\kappa \mathrm{a} \gg 1)$ こと, の 5 つである。ここで, 式中 $\varepsilon_{0} \mathrm{D}$ は溶媒の比誘電率, $\zeta$ はゼー夕電位, $\mathrm{g}$ は重力, $\phi$ は体粒子の体積濃度, $\rho_{2}$ は粒子密度, $\rho_{1}, \lambda, \eta$ はそ れぞれ溶媒の密度, 比電気伝導度, 粘度である。上記の 式は電気泳動速度の緩和時間効果に密接に関係してお り，実際の測定では式から分かるように入の影響を大き く受ける。したがって, 沈降電位は一般に非水溶媒分散 系で得られる值の方が水分散系で得られるそれよりはる かに大きな值が得られるので実用系に適用の際には溶媒
の比伝導度を測定するなどの注意が必要である。

\section{4 超音波法によるゼータ電位測定}

\section{4・1 超音波法によるゼータ電位評価の歴史と測定原理}

超音波の印加によって新たに電場や電流が誘起される 現象は, Electroacoustic Phenomena と呼ばれる。Debye は, この現象を 1933 年に予言したが6), 彼が最初に予 言した系はコロイド分散系ではなく, 水溶液中のカチオ ンやアニオンに対するものであった。カチオンやアニオ ンを含む水溶液に超音波を照射するとイオンの振幅強度 がイオン種の質量や水和状態によって異なり，それによ り溶液中の 2 点間で交流電場が形成されると彼は予言し た。実際, この電場は観測され, Ion Vibration Potential（IVP）と名付けられた。一方，イオンに対して誘 起されるのであれば高分子やコロイドに対しても同様の 現象が観測されるはずであるという推測から, 1938 年 に Hermans\&Rutgers は, Colloid Vibration Potential (CVP) が生じることを理論的に予測した ${ }^{7,8)}$ 。この予 測は，その後 10 年以上を経て Enderby \& Boothによっ て初めて観測された ${ }^{9,10)}$ 。それからさらに30 年の歳月 を経てようやく 1980 年初頭, 米国の Pen Kem 社から コロイド振動電位によるゼー夕電位測定装置 ${ }^{3)}$ や Matec Applied Science 社から ESA 法によるゼータ電位計 ${ }^{2)}$ が市販されるようになった。2013 年の本稿執筆時では, 米国 Dispersion Technology 社から超音波方式による ゼー夕電位計が販売されており, ESA 法については, Colloidal Dynamic 社と Matec 社から販売されている。

次に超音波式によるゼー夕電位測定の原理について説 明する。Fig. 4 に負に带電した粒子が電解質水溶液中で 振動している時の模式図を示す。粒子の回りの正電荷は 粒子表面の負電荷に対する対イオンで，粒子が右方向に 移動したことにより正電荷が流体力学的に左方向に偏っ ている様子を表している。そのため, 粒子左側には正電 荷が多く集まり，相対的に右側には負電荷が多くなって おり, 結果として歪んだ電気二重層が形成されている。

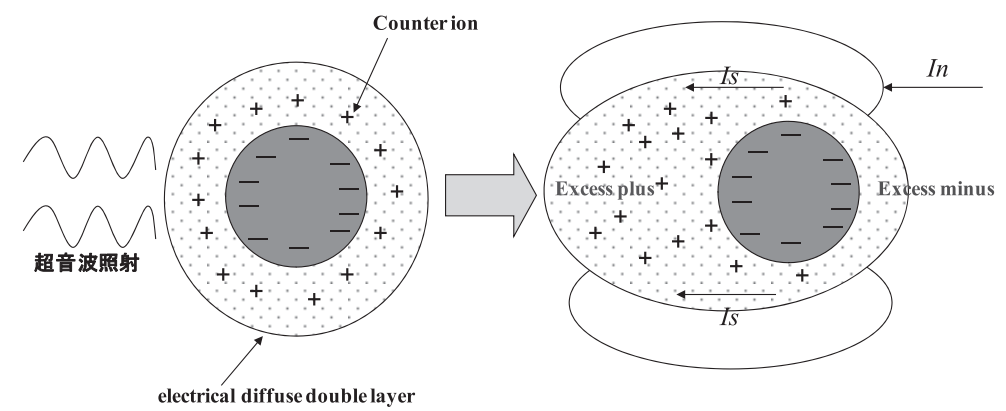

Fig. 4 超音波照射時の荷電粒子の二重層の状態。Fig. 3 の沈降時と同様に外力により二重層が変形し，双極子が形成されている 点に注意。 
したがって，この粒子の振動により双極子モーメントが 誘起されていることになる。超音波は粗密波であるので 超音波の発信子から離れた点ではこの双極子が集合して 配向し，巨大双極子すなわち電場を形成している。この 電場の形成により粒子表面伝導電流 (IS) が誘起され, それを補償するための電流（In）が生じる。測定装置は この二つの電流（CVI : Colloid Vibration Current）を 検出し, 装置に付属のソフトウェアにより, この Is, In からゼー夕電位が算出される。ESA 法では, 帯電して いる粒子に交流電場を印加することで粒子に振動を与 え，それにより生じた音圧変動を検出し，その大きさと 誘起電場の大きさからゼー夕電位が算出されるので, 顔 料系で多く見受けられる有機溶媒中での粒子の分散性を 評価する場合には, 粒子の帯電量が少ないので原理的に は超音波方式の方が適していると言える。

\section{$4 \cdot 2$ 測定装置とゼータ電位への変換理論}

超音波式によるゼー夕電位測定装置（米国 Dispersion Technology 社製 DT-300）の外観とコロイド振動電流 CVI (Colloid Vibration Current) を検出するプローブ 部分の写真を Fig. 5 に示す。この装置では, Fig. 5 に示 したプローブを懸濁液に直接浸漬し，ゼータ電位を測定 することができるので，七ルの洗浄が不要であるだけで なく，数 $\mu \mathrm{m}$ 以上の沈降し易い懸濁液中の粒子のゼー夕 電位測定や攪拌しながらのゼー夕電位測定が可能であ る。したがって，pH 滴定を行うことで表面電荷密度の 評価を行いながら同時にゼー夕電位の測定を行うことも 可能である。さらに, ここで紹介した装置に付属のソフ トウェアを用いると, кa（粒子半径と電気二重層厚さ との比）の違いにより理論を自動的に切り替えて最適な 理論式に従ってゼー夕電位を算出することができる。こ のことは最近需要が増してきたナノ粒子を非水溶媒系で 用いる場合にはとくに有効である。

次に，実際に測定したCVI あるいは ESA シグナルか らゼー夕電位に換算する理論的背景について解説する。 各原理に基づいた装置で測定される CVI や ESA シグナ
ルは電気音響シグナルと呼ばれ，いずれも O’Brienの提 唱した共通パラメータ ${ }^{11)}$ である “動的電気泳動移動度 (dynamic electrophoretic mobility : $\left.\mu_{\mathrm{d}}\right)$ ”に一旦変換さ れてからゼー夕電位が算出される。これは電気泳動移動 度とゼー夕電位の関係式に類似の形式にできるので直感 的に理解し易いからである。O'Brienの式に従うと動的 電気泳動移動度 $\mu_{\mathrm{d}}$ は式（2）のように表される。

$$
\mu_{\mathrm{d}}=\left(A_{\mathrm{ESA}} \text { or } A_{\mathrm{CVI}}\right) \frac{\rho_{\mathrm{m}}}{\phi\left(\rho_{\mathrm{p}}-\rho_{\mathrm{m}}\right)} \frac{1}{A(\omega) F(Z)}
$$

ここで $A_{\mathrm{CVI}}$ と $A_{\mathrm{ESA}}$ はそれぞれ CVI, ESA シグナルも 大きさで, $\mathrm{A}(\omega)$ はキャリブレーションによって決めら れる機械定数, $F(Z)$ は音響インピーダンスの関数, $\rho_{\mathrm{m}}, \rho_{\mathrm{p}}$ は溶媒と粒子の密度, $\phi$ は粒子の体積濃度である。

この $\mu_{\mathrm{d}}$ をゼー夕電位に関係づける際に条件を場合分 けして考える必要がある。1）電気二重層厚さが粒子半 径に比べて薄く，表面伝導度の寄与が小さい，すなわち デューヒン・ナンバー (Dukhin number, Du と略) ${ }^{12,13)}$ が小さい時に式が簡略化されること，

\section{$\kappa a \gg 1, \quad D u \ll 1$}

2）粒子間相互作用の有無により関係式が大きく異なる 点である。誌面の関係上，すべての場合を記述できない ので，1）の条件を満たし，かつ粒子間相互作用がない， すなわち比較的粒子濃度が薄い系での取り扱いと粒子間 相互作用（流体力学的相互作用および電気的相互作用） がある場合について考える。

先ず，粒子間相互作用がない場合には次式で関係づけ られる。

$$
\begin{aligned}
& \mu_{\mathrm{d}}=\frac{2 \varepsilon_{0} \varepsilon \zeta}{3 \eta} G(s)\left(1+F\left(\omega^{\prime}\right)\right) \\
& \text { ここで } \\
& G(s)=\frac{1+(1+j)_{\mathrm{s}}}{1+(1+j)_{\mathrm{s}}+j \frac{2_{S}^{2}}{9}\left(3+2 \frac{\rho_{\mathrm{p}}-\rho_{\mathrm{m}}}{\rho_{\mathrm{m}}}\right)}
\end{aligned}
$$

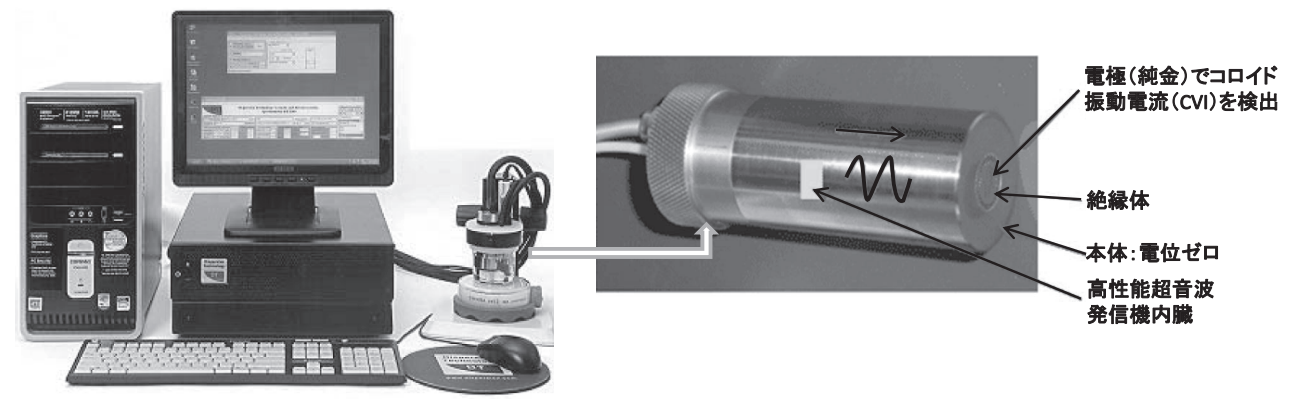

Fig. 5 超音波式によるゼー夕電位測定装置（米国 Dispersion Technology 社製 DT-300）の外観とコロイド振動電流 CVI（Colloid Vibration Current）を検出するプローブ部分の写真 


$$
\begin{aligned}
& F\left(\omega^{\prime}\right)=\frac{1+j \omega^{\prime}\left(1-\frac{\varepsilon_{\mathrm{p}}}{\eta}\right)}{2+j \omega^{\prime}\left(2+\frac{\varepsilon_{\mathrm{p}}}{\varepsilon}\right)} \\
& s^{2}=\frac{a^{2} \omega \rho_{\mathrm{m}}}{2 \eta} ; \omega^{\prime}=\frac{\omega}{\omega_{\mathrm{MW}}}
\end{aligned}
$$

で, $s^{2}$ および $\omega$ は, 動的電気泳動移動度 (dynamic electrophoretic mobility： $\mu_{\mathrm{d}}$ の周波数依存性を決める因 子, $j$ は $\sqrt{-1}$ を表す。したがって, $G(s)$ は慣性効果の周 波数依存性を反映し, $F\left(\omega^{\prime}\right)$ は電気二重層の MaxwellWagner 分極の効果を表す。

次に粒子間相互作用がある場合,

$$
\mu_{\mathrm{d}}=\frac{\varepsilon \varepsilon_{0} \zeta}{\eta} \frac{K_{\mathrm{s}}}{K_{\mathrm{m}}} \frac{\left(\rho_{\mathrm{p}}-\rho_{\mathrm{s}}\right) \rho_{\mathrm{m}}}{\left(\rho_{\mathrm{p}}-\rho_{\mathrm{m}}\right) \rho_{\mathrm{s}}}
$$

ここで， $\mathrm{K}_{\mathrm{s}}, \mathrm{K}_{\mathrm{m}}$ はそれぞれ懸濁液の伝導度および溶媒 の伝導度を表す。

\section{上記の式は，}

$$
\omega \ll \omega_{\mathrm{hd}}=\frac{\eta}{\rho_{\mathrm{m}} a^{2}} \text { および } \omega \ll \omega_{\mathrm{MW}}=\frac{K_{\mathrm{m}}}{\varepsilon_{0} \varepsilon}
$$

の流体力学的緩和が生じる周波数 $\left(\omega_{\mathrm{hd}}\right)$ と電気二重層 が分極する臨界周波数 $\left(\omega_{\mathrm{MW}}\right)$ に関する制限から両寄与 が無視できるときにのみ成立する。

\section{$4 \cdot 3$ 濃厚コロイド系でのゼータ電位測定例}

濃厚コロイド系の取り扱いの中で最も基本となる酸化 物コロイド粒子のゼー夕電位測定結果を紹介する。一般 に難溶性金属酸化物が水溶液中に分散している系では, 液相の $\mathrm{pH}$ の変化に対して強い緩衝作用を示すことが観 測されている。難溶性金属酸化物では, 通常の溶解・析 出が顕著に起こる訳ではないので, これは固体表面の化 学反応, すなわち表面水酸基でのプロトンおよび水酸化 物イオンの脱離・吸着による。これらイオンは電荷であ り酸・塩基作用も有するので, $\mathrm{pH}$ 応答すると同時に固 体表面に正および負電荷を与える。表面反応機構の詳細 については，文献を参照されたい ${ }^{14-18)}$ 。したがって， 液相の $\mathrm{pH}$ をシフトさせるとその $\mathrm{pH}$ 変化にしたがって 粒子が正や負に带電するが，電荷を持たない $\mathrm{pH}$ を電荷 零点, ゼー夕電位が零の $\mathrm{pH}$ を等電点と呼ぶ。この電荷 零点と等電点は酸化物の種類に依存して大きく異なるの で 14-18) 分散させる際には対象とする酸化物のそれら特 性を把握しておくことが基本となる。

Fig. 6 に粒子濃厚系スラリー $\mathrm{TiO}_{2}$ （ルチル, 粒子濃度 25 mass \% ）および $\mathrm{Al}_{2} \mathrm{O}_{3}$ （12 mass％）のゼー夕電位 $\mathrm{pH}$ 関係を示す。この結果よりそれぞれ金属酸化物粒子 の等電点は, $\mathrm{TiO}_{2}$ が 3.7 付近, $\mathrm{Al}_{2} \mathrm{O}_{3}$ が 9.5 付近に見られ

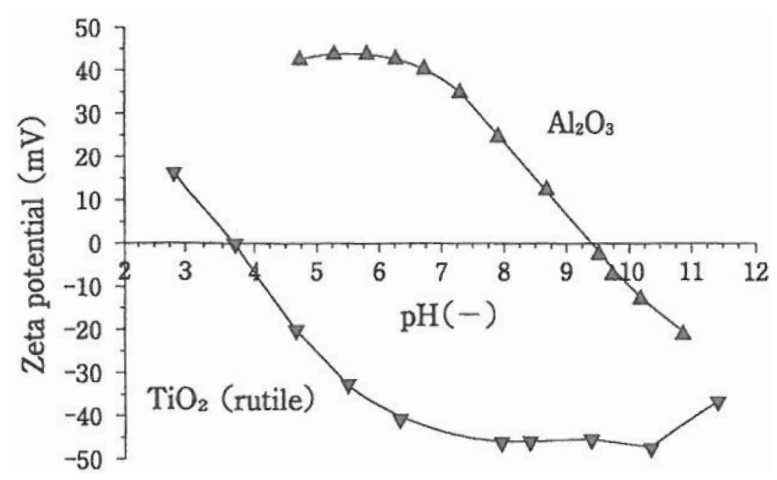

Fig. 6 粒子濃厚系スラリー $\mathrm{TiO}_{2}$ (ルチル、粒子濃度 25 mass\%）抽よ゙ $\mathrm{Al}_{2} \mathrm{O}_{3}$ (12 mass\%）のゼー夕電位 $\mathrm{pH}$ 関係

る。本来, 表面処理がされていない高純度の $\mathrm{TiO}_{2}$ 粒子 表面であれば, 表面は Ti と $\mathrm{OH}$ から構成されているの で等電点も電荷零点も一致して $\mathrm{pH} 6$ 付近にあるはずであ る。しかし, pH3.7 に等電点がシフトしていることから アニオン性物質, 例えば硫酸イオンや塩化物イオンなど が表面にコンタミとして残存している可能性がある。ま た, $\mathrm{pH} 6$ 付近で負の電荷を持つシリカ成分が表面処理と して被覆されている可能性も考えられる。いずれにして も滴定による電荷零点とゼー夕電位測定による等電点の 両方のデータを持つことで表面特性評価が可能となる。

また, 濃厚系の場合, ゼー夕電位の測定と同時に粒子 濃度が高い故に $\mathrm{pH}$ 変化から表面電荷密度の見積りも同 時に可能となる。従って, 上記のように等電点と電荷零 点の比較も可能となる。

\section{4・4 超音波スペクトロスコピーによる粒度分布結果 と in situ ゼータ電位評価の対比}

Fig. 7 に超音波スペクトロスコピーにより得られた $\mathrm{pH}$ 変化に対する分散・凝集状態の変化を粒度分布とし て比較してみた。（a)，(b) は $\mathrm{TiO}_{2}$ スラリーの pH3.9, 8.9 のときの結果であるが, 確かに $\mathrm{TiO}_{2}$ の等電点から遠い $\mathrm{pH} 8.9$ 付近ではメジアン径が $0.3 \mu \mathrm{m}$ であったものが, 等電点に近い $\mathrm{pH} 3.9$ のときには $2 \mu \mathrm{m}$ 付近にもピークが 見られ凝集粒子が存在していることが分かる。次に $\mathrm{Al}_{2} \mathrm{O}_{3}$ の結果を見てみよう。(c)，(d) は $\mathrm{Al}_{2} \mathrm{O}_{3}$ スラリー の $\mathrm{pH} 4.0,9.0$ のときの結果であるが， $\mathrm{TiO}_{2}$ のときに見 られた傾向と同様に等電点から遠い pH4.0 ではメジアン 径が $85 \mathrm{~nm}$ であるが，等電点に近い pH9.0のときには $400 \mathrm{~nm}$ 付近にもピークが見られこちらの酸化物の場合 にも凝集粒子が存在していることが分かる。以上のよう に液相の $\mathrm{pH}$ をシフトさせるとその $\mathrm{pH}$ 変化にしたがっ て粒子が正や負に带電し, その結果として再凝集の有無 が生じる。この一連の実験はゼー夕電位の測定も粒度分 布測定も超音波法により行ったのでスラリーを希釈する 
$\mathrm{TiO}_{2}$ (rutile) pH3.9

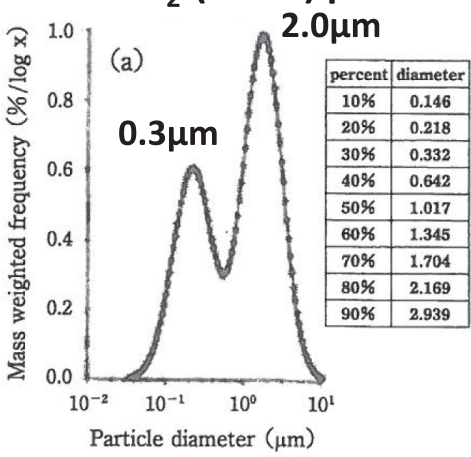

$\mathrm{Al}_{2} \mathrm{O}_{3} \mathrm{pH} 4.0$

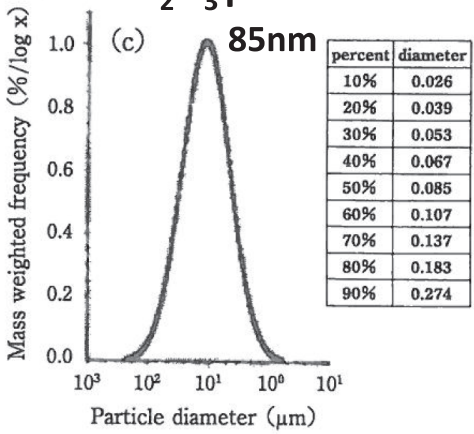

$\mathrm{TiO}_{2}$ (rutile) pH8.9

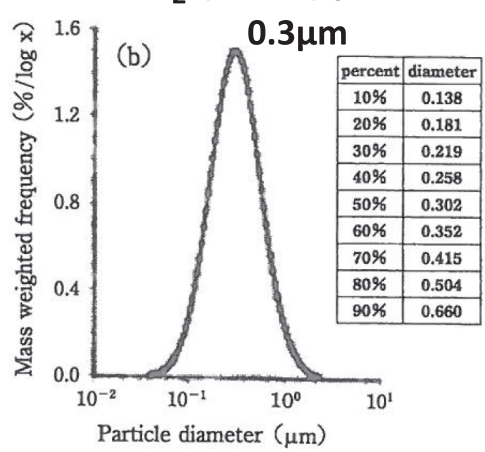

$\mathrm{Al}_{2} \mathrm{O}_{3} \mathrm{pH} 9.0$

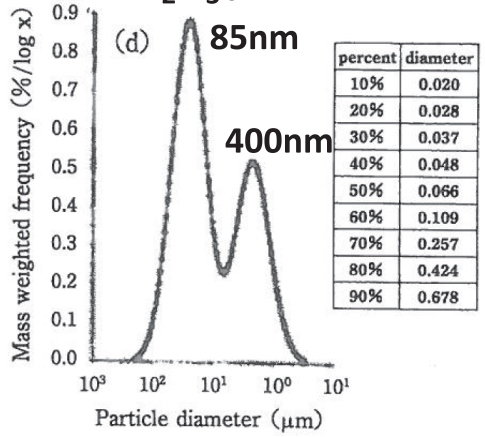

Fig. 7 Fig. 6 の条件下で測定した粒度分布

ことなく評価している。通常, 種々の $\mathrm{pH}$ に変化させた スラリーを希釈して測定する場合，スラリーと同じ $\mathrm{pH}$ でなおかつイオン強度も変化させずに行う必要がある。 これは $\mathrm{pH}$ とイオン強度に依存して界面状態が変化する ためであるが，実用系ではイオン濃度を測定してイオン 強度を調整する手間を省くためと希釈による分散・凝集 状態の変化を防ぐためにin situで測定されることをお 勧めする。

\section{5 おわりに}

濃厚コロイド系での界面動電現象について, 最近とく に注目されている超音波式ゼー夕電位測定法を中心に歴 史的背景から解説を行った。理論的背景は沈降電位で観 察される電気二重層の变形問題, すなわち表面伝導度の 寄与の問題に深く関係している。このことは電気泳動法 での Henry 係数やスモルコフスキー式の適用限界にも 関係する基礎的な事柄である。本稿が濃厚系での理論や 測定法について読者が興味を抱いて頂く機会になれば存 外の幸せである。最後に誌面の関係上, 濃厚系での様々 な場合に分けて理論式を紹介できなかったので，興味あ る方は参考文献を参考にして頂ければ幸いである。

\section{参考文献}

1）大藪権昭, 色材, 43, 208 (1970).

2) T. Oja, D. Cannon, G. L. Petersen, US Patent No.
4497208 (1985)

3) B. J. Marlow, D. Fairhurst, H. P. Pendse, Langmuir, 4, 611 (1988).

4) E. Dorn, Ann. Phys. (Leipzig) 10 (3): 46 (1878).

5) M. Von Smoluchowski, in Graetz Handbuch der Electriziat und des Magnetismus, vol. II, VEB Georg Thieme, Leipzig, p.385 (1921).

6) P. Debye, J. Chem. Phys., 1, 13 (1933).

7) J. Hermans, Phil. Mag., 25, 427 (1938).

8) A. Rutgers, Physica, 5, 46 (1938).

9) J. A. Enderby, Proc. Roy. Soc. (Lond.) A, 65, 329 (1951).

10) F. Booth, J. A. Enderby, Proc. Phys. Soc. 45, 321 (1952).

11) R. W. O’ Brien, J. Fluid Mech., 190, 71 (1988).

12) Measurement and Interpretation of Electrokinetic Phenomena, International Union of Pure and Applied Chemistry, Technical Report, Pure Appl. Chem., 77 (10), 1753 (2005) or J. of Colloid and Interface Science, 309, 194 (2007).

13) J. Lyklema, in Fundamentals of Interface and Colloid Science, Vol. 2, p.3, Academic Press (1995).

14）田里伊佐雄, 平井竹次, 化学総説, No. 7, 111-122（1975）.

15）虫明克彦, 増子昇, 生産研究, 29, [1], 2-7（1977）。

16) G. A. Parks, Chem. Rev., 65, 177 (1965).

17) A. S. Dukhin, P. J. Goetz, Langmuir, 12, 4987 (1996).

18) A. S. Dukhin and P. J. Goetz, "Ultrasound for Characterizing Colloids-Particle Sizing, Zeta Potential, Rheology-" in Studies in Interface Science, 15, Elsevier (2002). 